Research Article/Araştırma Makalesi

\title{
Examining Elementary Students' Attitude towards Learning Mathematics with Technology and Anxiety
}

\author{
Güney HACIÖMEROĞLU*1 \\ ${ }^{1}$ Çanakkale Onsekiz Mart University, Faculty of Education, Çanakkale, Turkey, \\ * Corresponding Author: guney@comu.edu.tr
}

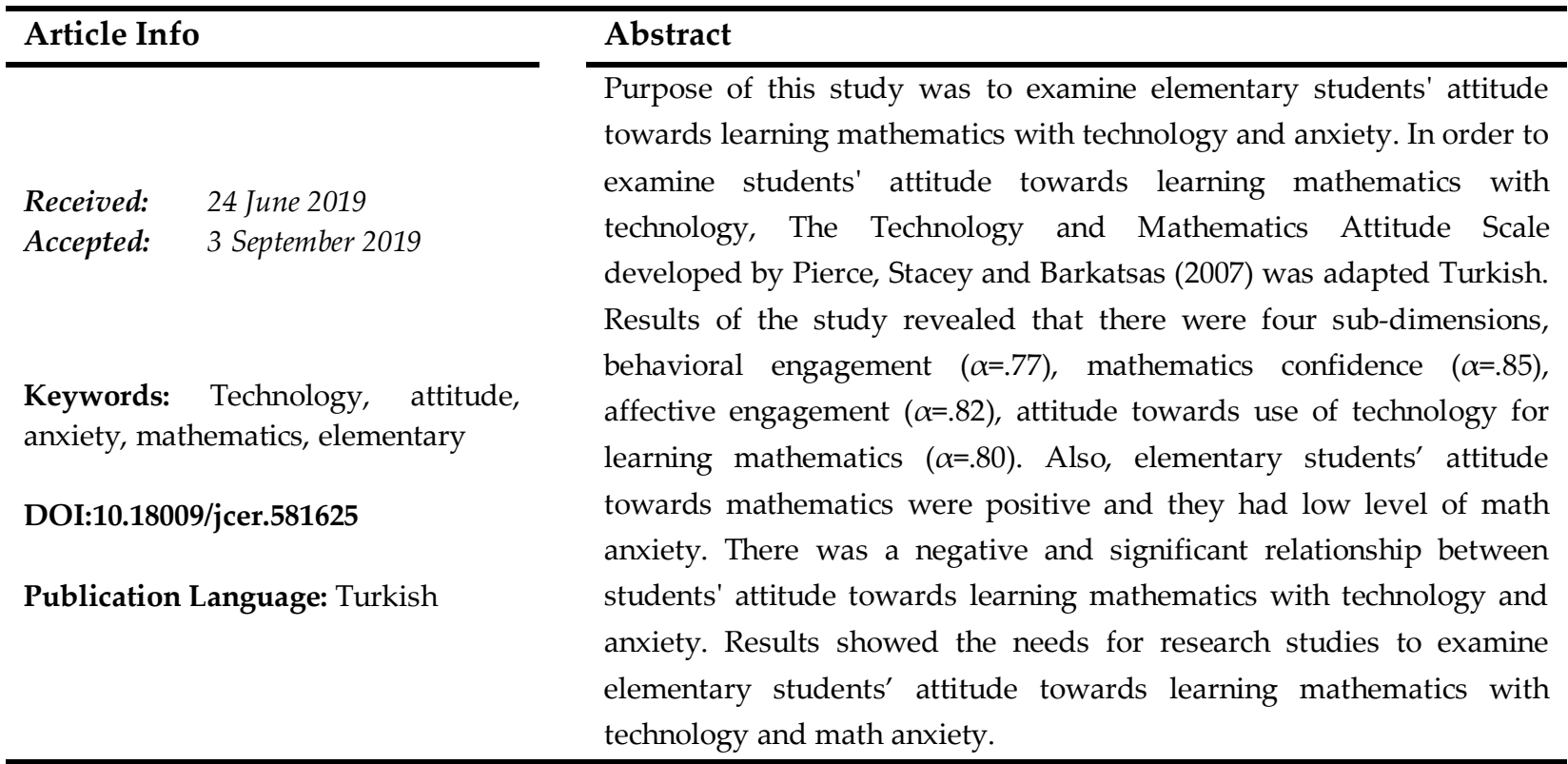

open access (a) CrossMark (c)

To cite this article: Hacıömeroğlu, G. (2019). İlkokul öğrencilerinin teknoloji destekli matematik öğrenmeye yönelik tutum ve kaygı düzeylerinin incelenmesi. Journal of Computer and Education Research, 7(14), 356-382. DOI:10.18009/jcer.581625

\section{İlkokul Öğrencilerinin Teknoloji Destekli Matematik Öğrenmeye Yönelik Tutum ve Kaygı Düzeylerinin İncelenmesi}

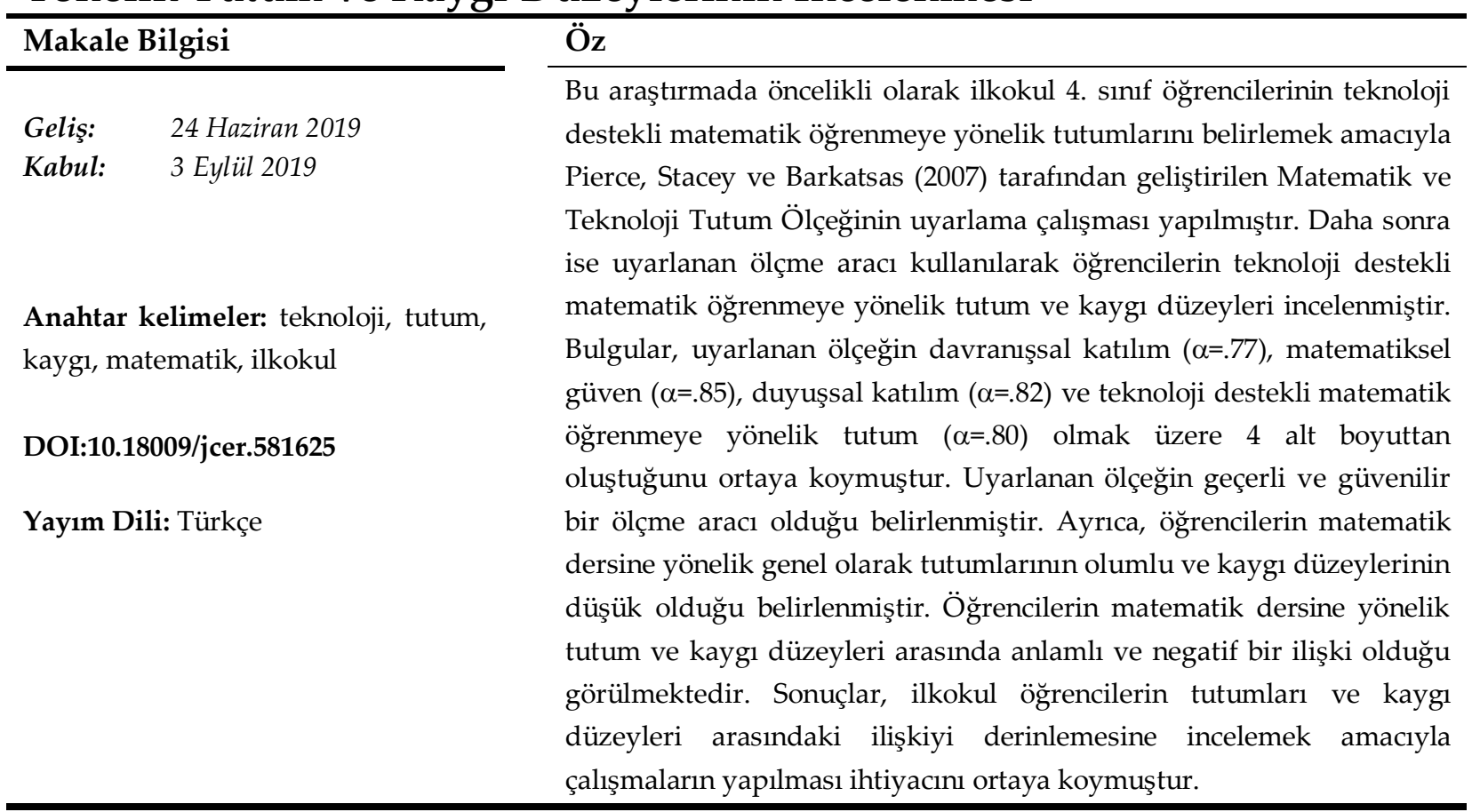




\section{Summary}

\section{Examining Elementary Students' Attitude towards Learning Mathematics with Technology and Anxiety}

\section{Introduction}

In Turkey, elementary students' attitude towards learning mathematics with technology and mathematics anxiety has been examined by few research studies. Instruments were developed and adapted to identify elementary students' attitude towards mathematics. After examining these research studies, there is a need for a reliable instrument to measure elementary students' attitude towards learning mathematics with technology. Purpose of this study was to examine elementary students' attitude towards learning mathematics with technology and anxiety. In order to examine students' attitude towards learning mathematics with technology, The Technology and Mathematics Attitude Scale developed by Pierce, Stacey and Barkatsas (2007) was adapted Turkish.

\section{Method}

In this quantitative research study, survey method approach was utilized. At first, this research study was intent to examine elementary students' attitude towards learning mathematics with technology. In order to examine elementary students' attitudes, Technology and Mathematics Attitude Scale developed by Pierce, Stacey and Barkatsas (2007) adapted to Turkish. Adapted Technology and Mathematics Attitude Scale includes four sub-dimensions: behavioral engagement, affective engagement, mathematics confidence, attitude towards mathematics learning with technology. After completing validity and reliability study of the scale, 4th year elementary students' attitude towards learning mathematics with technology was examined regarding gender and mathematics achievement. At the same time, elementary students' mathematics anxiety was also examined by using an instrument called, Mathematics Anxiety Rating Scale Elementary School form adapted by Baloğlu and Balgalmış (2010) was administered. Elementary students' mathematics anxiety was examined regarding gender and mathematics achievement. 
This rating scale includes five sub-dimensions called computation anxiety, application anxiety, and mathematics course anxiety, mathematics teacher anxiety and mathematics test anxiety. Also, the relationship between attitude towards mathematics learning with technology and mathematics anxiety was examined. In this study data were gathered in two phases. Data collection took place in a city located in Marmara region. In the first phase, data was collected for the validity and reliability study of the Technology and Mathematics Attitude Scale. For the adaptation study, data collected from 307 (151 girls and 156 boys) elementary students. In order to examine attitude towards mathematics and mathematics anxiety, data gathered from 311 (154 girls and 157 boys) elementary students. For the validity and reliability study, two programs SPSS 22 and LISREL 8.51 were used. SPSS 22 used for the factor analysis. LISREL 8.51 program is utilized for the confirmatory factor analysis. In order to analyze students' attitude towards learning mathematics with technology and mathematics anxiety, normality test was utilized. For the normality test, Kolmogorov-Smirnov was applied. In order to examine students' attitude and anxiety regarding gender and mathematics achievement two tests, Mann Whitney-U and Kruskal Wallis were used. Spearman's rho correlation was calculated to examine the relationship between these two variables.

\section{Results}

Results of the study revealed that there were four sub-dimensions behavioral engagement ( $\alpha=.77)$, mathematics confidence $(\alpha=.85)$, affective engagement $(\alpha=.82)$, attitude towards use of technology for learning mathematics $(\alpha=.80)$. Adapted scale, the Technology and Mathematics Attitude Scale include 16 items and placed on a 5-point Likert type. In addition, findings revealed that elementary students' attitudes towards learning mathematics with technology were positive and their anxieties were low. Results of the study revealed that their attitude towards learning with technology regarding behavioral engagement, mathematics confidence, affective engagement, attitude towards use of technology for learning mathematics were positive. There was no significant difference between students' scores on behavioral engagement, mathematics confidence, affective engagement, attitude towards use of technology for learning mathematics regarding gender. However, there was a significant difference between students' scores on behavioral engagement, mathematics confidence, and affective engagement regarding mathematics 
achievement. No significant difference was found between students' scores on attitude towards use of technology for learning mathematics regarding mathematics achievement. Findings revealed that students' mathematics anxiety level was low in general. Their anxiety scores regarding computation anxiety, application anxiety, and mathematics course anxiety were also low. However, their scores on mathematics teacher anxiety and mathematics test anxiety were moderate. There was no significant difference between students' scores on computation anxiety, application anxiety, and mathematics course anxiety, mathematics teacher anxiety and mathematics test anxiety regarding gender. However, a significant difference was found between students' scores on computation anxiety, application anxiety, and mathematics course anxiety, mathematics teacher anxiety and mathematics test anxiety regarding mathematics achievement. There was a negative and significant relationship between students' attitude towards learning mathematics with technology and anxiety. It seems as the students' attitude towards learning math with technology increases their anxiety decreases. Findings from this research study suggest that activities where elementary students would find interesting, enjoyable and engaging should be included in mathematics classes. Results of the research study revealed that elementary students had mathematics anxiety in early grades. It seems students felt anxious when interacting with teacher in mathematics classrooms as well as taking a math test. 


\section{Giriş}

Matematik günlük yaşamla ilişkilendirilmiş örnekleriyle zengin bir içeriğe sahiptir. Ancak, bu derse yönelik olumsuz bakış açısı ve duyuşsal özellikler (tutum, inanç vb.) geliştiren öğrenenler için matematik ve günlük yaşam arasındaki ilişkileri kurmak zor olabilmektedir. Araştırmalar, matematik dersine yönelik olumlu bir bakış açısına sahip olarak okula başlayan öğrencilerin edindikleri deneyimlerin matematik kaygıları ve tutumları üzerinde belirleyici bir rol üstlendiğini ortaya koymaktadır (Philippou \& Christou, 1998). Bu derse yönelik hissedilen kaygı ve tutumların öğrencilerin matematik başarılarında önemli bir rol oynadığı söylenebilir.

\section{Matematik Dersine Yönelik Tutum}

Araştırmalar matematik dersine yönelik tutumu farklı şekillerde tanımlamaktadır. Aiken (1974) tutumu matematik alanına veya bu kapsamda yer alan spesifik bir kavrama veya konulara (geometri, sözel problemler vb.) ilişkin performansına yönelik becerisi olarak tanımlamaktadır. Buna ek olarak, matematik dersini sevmenin sadece bu alan kapsamındaki problemleri çözmekle beraber terimleri ve sembolleri kullanma ve bunları yapmaktan hoşlanmayı kapsadığını vurgulamaktadır. Neale (1969) ise matematiğe yönelik olumsuz tutumun bu dersten hoşlanmama, etkinliklerinden kaçınma, bireyin matematikte iyi olmadığına yönelik inancı ve bu dersin bir işe yaramadığını düşünmesiyle yakından ilişkili olduğunun altını çizmektedir. Ancak, matematiğe yönelik olumlu tutumlar geliştiren bireylerin bu dersten hoşlandıkları, etkinliklere katıldıkları görülürken bireyin kendisini matematikte iyi olduğuna yönelik inancının önemli bir rol oynadığı söylenebilir. Bu tanımlar ve yapılan araştırmalar dikkate alındığında bireyin bu derse yönelik tutumu ile başarısı arasında anlamlı bir ilişki olduğu görülmektedir (Ma \& Kishor, 1997). Öğrenim hayatlarında bu derste başarılı olan öğrencilerin gelecekte daha fazla matematik dersi alma eğilimi gösterdiği (Haladyna, Shaughnessy \& Shaughnessy, 1983) ve matematikle ilişkili alanlarda öğrenim hayatlarına devam etme ve kariyer yapma eğiliminde oldukları söylenebilir. Araştırmalar öğrencilerin matematik dersine yönelik oluşturdukları tutum, inanç ve kaygı gibi duyuşsal faktörlerin bu dersteki başarılarıyla yakından ilişkili olduğunu vurgulamaktadır (Ma \& Kishor, 1997). Ma ve Kishor (1997) tarafından yapılan meta-analitik çalışma matematiğe yönelik negatif tutumun bu dersle zayıf bir ilişki ve katılımla beraber 
düşük performansa yola açtığını vurgulamaktadır. Öğrenciler pozitif tutuma sahip olduklarında bu durumun matematik başarıları üzerinde olumlu bir etkisi olduğu ortaya konmuştur (House, 1995). Ancak, bazı araştırmalar ise matematiğe yönelik tutum ile başarı arasında zayıf bir ilişki olduğunu vurgulamaktadır (Aiken, 1970; Ma \& Kishor, 1997). Bazı çalışmalar ise öğrencilerin hissettiği güven ve kaygı duygusuyla beraber matematiğin kullanımı, eğlenceli olmasının bu derse yönelik tutumları üzerinde önemli bir rol oynadığını belirtmiştir (Tapia \& Marsh, 2004).

\section{Matematik Kaygısı}

Matematik dersine yönelik hissedilen kayg1, "sayıların manipülasyonuna ve matematik problemlerinin çeşitli günlük yaşam ve akademik durumlar içinde çözümüne engel olan gerginlik ve kayg1 duygusu" (Richardson \& Suinn, 1972, s.551) olarak tanımlamaktadır. Araştırmalar matematik kaygısı ile bu derste gösterilen başarı arasında anlamlı bir ilişki olduğunu vurgulamaktadır (Kutluca, Alpay \& Kutluca, 2015; Richardson \& Suinn, 1972; Zakaria \& Nordin, 2008). Ashcrafts (2002) kaygıyı öğrencilerin matematikle ilişki eğitim ve kariyer edinme yolundaki en önemli engellerden birisi olarak göstermektedir. Matematik kaygısı bu dersten hoşlanmama ve bununla ilişkili herhangi bir çalışmayla uğraşmak istememek olarak karşımıza çıkabilmektedir (Chipman, Kranz \& Silver, 1992). Matematik kaygı düzeyi yüksek öğrencilerin basit bir matematiksel işlemi yaparken stresli ve endişeli oldukları ve matematik başarılarının olumsuz yönde etkilendiği belirlenmiştir (Hembre, 1990). Benzer şekilde, Mutlu, Söylemez ve Yasul (2017) ilkokul öğrencilerinin matematik kaygıları ve başarı düzeyleri arasında anlamlı ve çift yönlü negatif bir ilişki olduğunu belirlemiştir. Öğrencilerin matematik başarısı artıkça kaygı düzeylerinin azaldığını aynı şekilde kaygı düzeyi azaldıkça başarı seviyesinin arttı̆̆ı tespit edilmiştir. Cinsiyetin bir değişken olarak ele alınıp yapılan çalışmalar incelendiğinde iki farklı durumun ortaya çıktığı görülmektedir. Bazı çalışmalarda (Arı, Savaş \& Konca, 2010; Dursun \& Bindak, 2011; Yüksel-Şahin, 2008) kız ve erkek öğrencilerin matematik kayg1 düzeyleri arasında anlamlı farklılık görüldüğü ortaya konulmuştur. Ancak, bazı araştırma sonuçlarının bu durumun tersine, k1z ve erkek öğrencilerin matematik kaygı düzeyleri arasında anlamlı bir farklılık olmadığı görülmektedir (Yaratan \& Kasapoğlu 2012). 
Öğrencilerin teknoloji destekli matematik öğrenmeye yönelik tutumlarının inceleyen çalışmalar incelendiğinde bu çalışmaların ağırlıklı olarak ortaokul, lise ve üniversite öğrencileriyle yapıldığı dikkate çekmektedir (Barkatsas, Kasimatis \& Gialamas, 2009; Duru, Peker \& Akçakın, 2010; Fogarty, Cretchley, Harman, Ellerton, \& Konki, 2001; Galbraith \& Haines,1999; Pierce, Stacey \& Barkatsas, 2007). Ulusal düzeyde yürütülen çalışmalar incelendiğinde, Çelik ve Ceylan (2009) lise öğrencilerinin bilgisayar ve matematik dersine yönelik tutumlarının olumlu olduğunu belirlemiştir. Duru, Peker ve Akçakın (2010) ise lise öğrencilerinin matematik dersinde bilgisayar kullanımına yönelik tutumlarının olumlu olduğunu ortaya koymuştur. Barkatsas, Kasimatis ve Gialamas, (2009) dokuzuncu sınıf öğrencilerinin teknoloji destekli matematik öğrenmeye yönelik tutumlarının olumlu olduğunu belirlemiştir. Barkatas ve diğerleri (2009) erkek öğrencilerin kızlara kıyasla teknoloji destekli matematik öğrenmeye yönelik tutumlarının daha gelişmiş olduğu belirlenmiştir. Yapılan araştırmaların ağırlıklı olarak lise öğrencileriyle yürütülmüş olması, ilkokul öğrencilerinin teknoloji destekli matematik öğrenmeye yönelik tutumlarının belirlenmesine yönelik ihtiyacını ortaya koymuştur. Bununla beraber, ilkokul öğrencilerinin matematik kaygı düzeylerini inceleyen çalışmaların sayısında son yıllarda bir artış olduğu görülmektedir (Mutlu, Söylemez \& Yasul, 2017; Yüksel-Şahin, 2008). Ancak, bu durum ilkokul öğrencilerin matematik kaygı düzeylerini incelemeye yönelik daha fazla çalışma yapılması ihtiyacını ortaya koymuştur.

Ülkemizde öğretim teknolojilerindeki gelişmelerle beraber sınıflara akıllı tahta, projeksiyon veya bilgisayar sağlanarak öğrenme-öğretme sürecinde bu araçların aktif ve etkili bir şekilde kullanılması hedeflenmiştir. Ancak, sınıf ortamlarında bilgisayar destekli matematik öğretimi yaygın olarak kullanılmasına rağmen öğrencilerin teknoloji destekli matematik öğrenmeye yönelik tutumlarını (Barkatsas, Kasimatis, Gialamas, 2009; Duru, Peker \& Akçakın, 2010; Pierce, Stacey \& Barkatsas, 2007; Reed, Drijvers \& Kirschner, 2010) ve kayg1 düzeylerini (Mutlu, Söylemez \& Yasul, 2017; Yüksel-Şahin, 2008) inceleyen çalışmaların ayrı ayrı ele alındığı ve genellikle ortaokul ve üzeri sınıf düzeylerini kapsadığı dikkat çekmektedir. Yapılan bu çalışmaların 1şığında, ilkokul öğrencilerinin teknoloji destekli matematik öğrenmeye yönelik tutumları ile kaygı düzeylerini beraber inceleyen bir çalışmanın yapılması ihtiyacını ortaya koymuştur. 


\section{Geliştirilen ve Uyarlanan Ölçekler}

Araştırmalar öğrencilerin matematik öğrenmeye yönelik tutumlarını incelemek amacıyla farklı ölçme araçlarının geliştirildiğini ve uyarlandığını göstermektedir. Bu ölçme araçlarına bakıldığında, ilkokul öğrencilerinin matematik dersine yönelik tutumlarını incelemek amacıyla geliştirilen iki ölçme aracının olduğu görülmektedir (Gülburnu \& Yıldırım, 2015; Haciömeroğlu, 2017; Duru, Peker \& Akçakın, 2010). Ortaöğretim öğrencilerinin teknoloji destekli matematik öğrenmeye yönelik tutumlarını belirlemek amacıyla Pierce, Stacey ve Barkatsas (2007) tarafından geliştirilen Matematik ve Teknoloji Tutum Ölçeğinin Duru, Peker ve Akçakın (2010) tarafından Türkçeye uyarlama çalışmasının yapıldığ1 görülmektedir. Uyarlanan ölçeğin lise düzeyinde öğrenim gören öğrencilerin teknoloji destekli matematik öğrenmeye yönelik tutumlarını belirlemek amacıyla kullanılabilecek geçerli ve güvenilir araç olduğu belirlenmiştir. Gülburnu ve Yıldırım (2015) ilkokul ve ortaokul (4., 5., 6., 7. ve 8.) öğrencilerinin matematik dersine yönelik tutumlarını belirlemek amacıyla bir ölçek geliştirmiştir. Hacıömeroğlu (2017) ise Lim ve Chapman (2013) tarafından uyarlanan matematik dersine yönelik tutum ölçeğini ilkokul 4. sınıf öğrencileri için geçerlik ve güvenirlik çalışmasını yaparak Türkçeye uyarlamıştır. Uyarlanan ve geliştirilen ölçme araçları incelendiğinde, ilkokul öğrencilerinin teknoloji destekli matematik öğrenmeye yönelik tutumlarını incelemeye yönelik bir ölçme aracına olan ihtiyacı ortaya koymuştur. Bu sebeple, bu çalışmanın ilk aşamasında ilkokul öğrencilerinin teknoloji destekli matematik öğrenmeye yönelik tutumlarını belirlemek amacıyla Pierce, Stacey ve Barkatsas (2007) tarafından geliştirilen Matematik ve Teknoloji Tutum Ölçeğinin ilkokul 4. sınıf için Türkçeye uyarlama çalışmasının yapılması amaçlanmıştır. Son yıllarda ilkokul öğrencilerinin tutum ve kaygı düzeylerini erken yaşlarda belirlemeye yönelik çalışmaların arttığ1 görülmektedir. Öğrencilerin matematik dersine yönelik erken yaşlarda edindikleri olumlu ve olumsuz tutum ile kaygı düzeylerini belirlemek öğrenme-öğretme süreci açısından önem taşımaktadır Bu sebeple, araştırmanın ikinci aşamasında ilkokul 4. sınıf öğrencilerinin teknoloji destekli matematik öğrenmeye yönelik tutumları ile matematik kaygı düzeylerinin incelenmesi amaçlamıştır. 
Bu araştırma kapsamında aşağıdaki araştırma soruları ele alınmıştır:

1. İlkokul 4. sınıf öğrencilerin teknoloji destekli matematik öğrenmeye yönelik tutumları ne düzeydedir?

2. Cinsiyet değişkenine göre ilkokul 4. sınıf öğrencilerin teknoloji destekli matematik öğrenmeye yönelik tutumları arasında anlamlı bir fark var mıdır?

3. Başarı değişkenine göre ilkokul 4. sınıf öğrencilerin teknoloji destekli matematik öğrenmeye yönelik tutumları arasında anlamlı bir fark var mıdır?

4. İlkokul 4. sınıf öğrencilerin matematik kaygı düzeyleri ne düzeydedir?

5. Cinsiyet değişkenine göre ilkokul 4. sınıf öğrencilerin matematik kayg1 düzeyleri arasında anlamlı bir fark var mıdır?

6. Başarı değişkenine göre ilkokul 4. sınıf öğrencilerin matematik kaygı düzeyleri arasında anlamlı bir fark var mıdır?

7. Öğrencilerin teknoloji destekli matematik öğrenmeye yönelik tutumları ile matematik kaygı düzeyleri arasında anlamlı bir ilişki var mıdır?

\section{Yöntem}

$\mathrm{Bu}$ çalışmada nicel araştırma deseni kullanılmıştır. Bu araştırmada öncelikli olarak ilkokul 4. sınıf öğrencilerinin teknoloji destekli matematik öğrenmeye yönelik tutumlarını belirlemek amacıyla Pierce, Stacey ve Barkatsas (2007) geliştirilen bir ölçme aracının Türkçeye uyarlama çalışmasının yapılması için nicel araştırma yöntemlerinden tarama modeli kullanılmıştır. Tarama modeli, evren hakkında genel bir yargıya ulaşmak amacıyla evrenin tümü veya evrenden alınacak örneklem üzerinden yapılan düzenlemeler olarak tanımlanmaktadır (Karasar, 2003). İkinci aşamada ise ilkokul 4. sınıf öğrencilerinin teknoloji destekli matematik öğrenmeye yönelik tutumları ve kaygı düzeyleri arasındaki ilişkinin incelenmesi amaçlandığından ilişkisel tarama modeli kullanılmıştır. 


\section{Çeviri Çalışması}

Matematik ve Teknoloji Tutum Ölçeğinde (MTTÖ) yer alan 20 madde önce araştırmacı tarafından Türkçeye çevrilmiştir. İki matematik eğitimi, iki öğretmen eğitimi ve bir İngiliz dili eğitimi üzerine çalışan 5 kişilik bir uzman grubu oluşturularak ölçeği Türkçeye çevirmeleri istenmiştir. Uzmanlardan Türkçeye çevrisini yaptıkları ölçekte yer alan maddelerin özgün haline uygun ve anlaşılır olmasına dikkat etmeleri istenmiştir. Araştırmacı ve uzmanlar tarafından birbirinden bağımsız olarak yapılan bu değerlendirmeler bir araya getirilerek incelenmiştir. Yapılan incelemelerde öncelikle ortak yönlerine bakılmıştır. Çeviriler dikkate alındığında uzmanların ve araştırmacıların çoğunlukla ölçekte yer alan her maddenin özgün haline uygun ve anlaşılır olduğu konusunda tutarlı bir performans gösterdiği tespit edilmiştir. Çevirilerdeki farklılıklar, maddeler Türkçeye çevrilirken aynı cümlenin farklı şekillerde ifade edilebilmesine bağlı olarak ortaya çıkmıştır. Ortaya çıkan farklılıklar ve çelişkili durumlar, uzmanlar ve araştırmacılar bir araya getirilerek yaptıkları çeviriler incelenerek giderilmiş ve ortak çeviri formu oluşturulmuştur. Son şekli verilen ölçek Türkçe yazım ve anlama kurallarına uygunluğu açısından bir Türkçe eğitimi uzmanı tarafından tekrar incelendikten sonra uygulamaya hazır hale getirilmiştir.

\section{Örneklem}

Araştırmanın örneklemini Marmara bölgesinde bir il merkezindeki ilkokullarda öğrenim gören 4. sınıf öğrencileri oluşturmaktadır. Matematik ve Teknoloji Tutum Ölçeğinin (MTTÖ) Türkçeye uyarlama çalışması kapsamında veriler 151 erkek ve 156 kız olmak üzere toplam 307 dördüncü sınıf öğrencisinden toplanmıştır. MTTÖ'nün test-tekrar test güvenirlik çalışması 30 erkek ve $40 \mathrm{kız}$ olmak üzere 4 . sınıfta öğrenim gören toplam 70 öğrenciden toplanan veriler kullanılarak hesaplanmıştır. Buna ek olarak, öğrencilerin teknolojiyle beraber matematik öğrenmeye yönelik tutumları ve matematik kaygı düzeylerini incelemek amacıyla veriler 157 erkek ve 154 kız olmak üzere toplam 311 dördüncü sınıf öğrencisinden toplanmıştır. 
Veri Toplama Araçları

Matematik ve Teknoloji Tutum Ölçeği (MTTÖ)

Bu ölçek Pierce, Stacey ve Barkatsas (2007) tarafından geliştirilmiş olup ortaokul öğrencilerinin teknolojiyle beraber matematik öğrenmeye yönelik tutumlarını belirlemek amacıyla geliştirilmiştir. Özgün ölçekte 20 madde yer almaktadır ve 5'li Likert (hiç, nadiren, genellikle, çoğu zaman, her zaman) tipindedir (Bakınız Ek 1). Ölçek, matematiksel güven $(9,10,11,12)$, teknolojiye kullanımıyla ilgili güven $(5,6,7,8)$, teknoloji destekli matematik öğrenmeye yönelik tutum $(17,18,19,20)$, duyuşsal katılım $(13,14,15,16)$ ve davranışsal katılım $(1,2,3,4)$ olmak üzere 5 alt boyuttan oluşmaktadır. Ölçekte yer alan alt boyutlar için Cronbach alfa güvenilirlik katsayısı sırasıyla .87, .89, .79, .72 ve .65 olarak hesaplanmıştır.

Matematik Kaygısı Derecelendirme Ölçeği (MKDÖ)

Bu ölçek Suinn (1988) tarafından geliştirilmiş olup Türkçeye Baloğlu ve Balgalmış (2010) tarafından uyarlanmıştır. Ölçeğin uyarlama çalışması 3.-8. sınıfta öğrenim gören öğrencilerden toplanan veriler üzerinden gerçekleştirilmiştir. Uyarlanan ölçekte 26 madde yer almaktadır ve 5’li Likert (hiç, çok az, orta derecede, çok ve çok fazla) tipindedir. Ölçek beş alt boyuttan oluşmaktadır: Matematik hesaplama kaygısı (1, 2, 3, 4, 10, 19, 20), uygulama kaygısı $(5,6,21,22,23,24)$, matematik dersine yönelik kaygı $(7,11,14)$, matematik sinav kaygısı $(13,15,16,17,18)$ ve matematik öğretmeni kaygısıdır $(8,9,12,25,26)$. Ölçeğin bütünü için Cronbach alfa güvenirlik katsayısı .94 olarak hesaplanmıştır. Alt faktörler için hesaplanan güvenirlik katsayısının .77 ile .86 arasında değerler aldığı belirlenmiştir.

\section{İşlem}

Araştırmada öncelikle ilkokul 4. sınıf öğrencilerine çalışma hakkında bilgi verilmiştir. Öncelikli olarak veriler Matematik ve Teknoloji Tutum Ölçeğinin Türkçeye uyarlama çalışması için toplanmıştır. Ölçeğin uyarlama çalışması tamamlandıktan sonra, ilkokul 4. sınıf öğrencilerinin teknolojiyle beraber matematik öğrenmeye yönelik tutumları ve matematik kaygı düzeylerini incelemek amacıyla yeniden veri toplanmıştır. 


\section{Verilerin Analizi}

Toplanan veriler SPSS 22.0 programına aktarılmıştır. Uyarlama çalışması yapılan ölçeğin faktör analizine uygun olup olmadığını belirlemek amacıyla açımlayıcı faktör analizi yapılmıştır. Uyarlanan ölçeğin geçerlik çalışması kapsamında test tekrar test çalışması yapılmıştır. Açımlayıcı faktör analizi sonucunda oluşan yapının ne derece uygun olduğunu belirlemek amacıyla LISREL 8.51 programı kullanılarak doğrulayıcı faktör analizi yapılmıştır. Ölçeğin güvenilirliğini belirlemek amacıyla ölçeğin bütünü ve alt boyutları için Cronbach alfa güvenilirlik katsayısı hesaplanmıştır.

Öğrencilerin teknolojiyle beraber matematik öğrenmeye yönelik tutumları ve matematik kaygı düzeylerini incelemek amacıyla ölçeklere vermiş oldukları cevapların değerlendirilmesinde grup aralık katsayısı değeri kullanılmıştır. Grup aralık katsayısı değeri “ölçme sonuçları dizisindeki en büyük değer ile en küçük değer arasındaki farkın belirlenen grup sayısına bölünmesiyle (Kan, 2009, s. 407)" hesaplanmaktadır. İlkokul 4. sınıf öğrencilerinin Matematik ve Teknoloji Tutum Ölçeğine vermiş oldukları yanıtlar değerlendirilirken 4.50-5.00 her zaman, 3.50-4.49 çoğu zaman, 2.50-3.49 genellikle, 1.50-2.49 nadiren, 1.00-1.49 hiç aralıkları temel alınarak yorumlanmıştır. Buna ek olarak, öğrencilerin Matematik Kaygısı Derecelendirme Ölçeğine vermiş olduğu yanıtlar değerlendirilirken 4.505.00 çok fazla, 3.50-4.49 çok, 2.50-3.49 orta derecede, 1.50-2.49 çok az, 1.00-1.49 hiç aralıkları dikkate alınmıştır.

Betimsel istatistikler (aritmetik ortalama ve standart sapma vs.) teknolojiyle beraber matematik öğrenmeye yönelik tutum ve matematik kaygı düzeylerini ortaya koymak amacıyla hesaplanmıştır. Toplanan verilerin normal dağılıma sahip olup olmadığını belirlemek amacıyla normallik testi yapılarak Kolmogorov-Smirnov testi yapılmıştır (Field, 2005). Öğrencilerin cinsiyet değişkenine göre tutumları ve kaygılarına yönelik görüşleri arasında anlamlı bir farklılık olup olmadığını belirlemek amacıyla Mann Whitney-U testi yapılmıştır. Öğrencilerin başarı düzeyi ile tutumları ve kaygılarına yönelik görüşleri arasında anlamlı bir farklılık olup olmadığını belirlemek amacıyla Kruskal Wallis testi yapılmıştır. MTTÖ ve MKDÖ alt boyutlarına ilişkin ortalama puanları kullanılarak öğrencilerin teknoloji destekli matematik öğrenmeye yönelik tutumları ve kaygı düzeyleri arasındaki ilişkinin incelenmesi amacıyla Spearman's rho korelasyon katsayıları hesaplanmıştır. 


\section{Bulgular}

Matematik ve Teknoloji Tutum Ölçeği Geçerlik Çalışması Bulguları

Matematik ve Teknoloji Tutum Ölçeğinin geçerlik çalışması kapsamında KaiserMeyer-Olkin (KMO) değeri ve Barlett Küresellik Testi yapılmıştır.

Tablo 1. Matematik ve Teknoloji Tutum Ölçeği Açımlayıcı Faktör Analizi Sonuçları

\begin{tabular}{|c|c|c|c|c|c|c|}
\hline Madde & $\mathrm{DaK}$ & MG & DuK & TDMÖT & $\mathrm{r}$ & a \\
\hline $\mathrm{T} 1$ & .724 & & & & .614 & .88 \\
\hline T3 & .720 & & & & .580 & .89 \\
\hline $\mathrm{T} 2$ & .707 & & & & .635 & .88 \\
\hline $\mathrm{T} 4$ & .678 & & & & .526 & .89 \\
\hline T10 & & .772 & & & .654 & .88 \\
\hline T9 & & .743 & & & .684 & .88 \\
\hline T11 & & .716 & & & .648 & .88 \\
\hline T12 & & .574 & & & .663 & .88 \\
\hline T16 & & & .814 & & .565 & .89 \\
\hline T15 & & & .762 & & .610 & .88 \\
\hline T13 & & & .754 & & .594 & .89 \\
\hline T14 & & & .739 & & .713 & .88 \\
\hline T18 & & & & .734 & .451 & .89 \\
\hline T20 & & & & .730 & .359 & .89 \\
\hline T19 & & & & .729 & .394 & .89 \\
\hline T17 & & & & .544 & .486 & .89 \\
\hline $\begin{array}{l}\text { Cronbach } \\
\text { alfa }\end{array}$ & .77 & .85 & .82 & .80 & & .89 \\
\hline
\end{tabular}

DaK: davranışsal katılım, MG: matematiksel güven, DuK: duyuşsal katılım, TDMÖT: teknoloji destekli matematik öğrenmeye yönelik tutum

Analiz sonuçlarına göre KMO değeri .915 olarak hesaplanmıştır. Bu değerin .90 ve üzerinde oluşu mükemmel olarak kabul edilmekte ve verilerin faktör analizi için uygun olduğu şeklinde yorumlanmaktadır (Çokluk, Şekercioğlu \& Büyüköztürk, 2010; Tavşancıl, 2005). Barlett küresellik testi sonuçları, $X^{2}{ }_{(946)}=11071.045 \mathrm{p}<.01$ olması sebebiyle ki-kare değerinin 0.01 düzeyinde anlamlı olduğunu ortaya koymuştur. Elde edilen bu bulgular, verilerin açımlayıcı faktör analizi için uygun olduğunu ortaya koymuştur. Uyarlama çalışması yapılan ölçeğin faktör yapısını ortaya koymak amacıyla varimax döndürme 
yöntemi seçilmiştir. Bu yöntem verilerin dağılımının tek boyutlu olup olmadığını belirlemek amacıyla kullanılmıştır. Ölçekte yer alan maddelerin binişiklik ve faktör yük değerleri ve kabul düzeyini karşılayıp karşılamadığı incelenmiştir. Elde edilen bulgular, özdeğeri1'de büyük dört faktörün $(7.462,2.190,1.455,1.014)$ olduğunu ortaya koymuştur. Bu faktörlerden birincisi tek başına varyansın \%37.310'unu açıklamaktadır. Dört faktör beraber toplam varyansın \%60.874'ünü açıklamaktadır. Klein (1986) madde toplam test korelasyon değerleri dikkate alındığında .20 değerinin alt sınır olması gerektiğini vurgulamaktadır. Bu sebeple, uyarlama çalışması yapılan ölçekte yer alan 4 madde $(5,6,7,8)$ için hesaplanan madde toplam test korelasyon değerlerinin .20'nin altında olması sebebiyle çıkarılmıştır. Ölçekte yer alan diğer 16 madde için hesaplanan madde toplam test korelasyon değerlerinin '.359-.713' aralığında olduğu belirlenmiştir. Uyarlanan ölçekteki 16 maddenin binişiklik ve faktör yük değerlerinin kabul düzeyini karşıladığı belirlenmiştir.

Uyarlanan ölçek 4 alt boyuttan oluşmaktadır. Bunlar sırasıyla davranışsal katılım $(1,2,3,4)$, matematiksel güven $(9,10,11,12)$, duyuşsal katılım $(13,14,15,16)$ ve teknoloji destekli matematik öğrenmeye yönelik tutum $(17,18,19,20)$ olarak adlandırılmıştır.

Matematik ve Teknoloji Tutum Ölçeği Güvenilirlik Çalışması Bulguları

Uyarlanan ölçeğe ilişkin test tekrar test çalışması kapsamında birinci ve ikinci uygulamaya ilişkin ortalama ve standart sapma hesaplanmıştır. Birinci uygulamada bu değer $3.79 \pm 0.81$ olarak ikinci uygulamada ise $4.06 \pm 0.77$ olarak hesaplanmıştır. Test tekrar test çalışması için hesaplanan Pearson korelasyon katsayısının .824 p=.001 düzeyinde anlamlı olduğu belirlenmiştir. Ölçek alt boyutları için Cronbach alfa güvenirlik katsayısı sırasıyla $.77, .85, .82, .80$ olarak hesaplanmıştır. Ölçeğin bütünü için güvenirlik katsayısı .89 olarak hesaplanmıştır (Bakınız Tablo 1).

Matematik ve Teknoloji Tutum Ölçeği Doğrulayıcı Faktör Analiz Bulguları

Doğrulayıcı faktör analizinden elde edilen uyum indeksi değerleri sırasıyla $\chi^{2}=212.52$, $\mathrm{sd}=98 \mathrm{RMR}=.08, \quad \mathrm{RMSEA}=.0061, \quad \mathrm{SRMR}=.078, \mathrm{GFI}=.92, \mathrm{AGFI}=.89 ， \mathrm{AGFI}=.84 ， \mathrm{NFI}=.86$, $\mathrm{NNFI}=.90, \mathrm{CFI}=.92$ olarak hesaplanmıştır. Ki-kare değerinin serbestlik derecesine oranı $\left(\chi^{2} / \mathrm{sd}\right) 2.16^{\prime} \mathrm{d} ı \mathrm{r}$. 


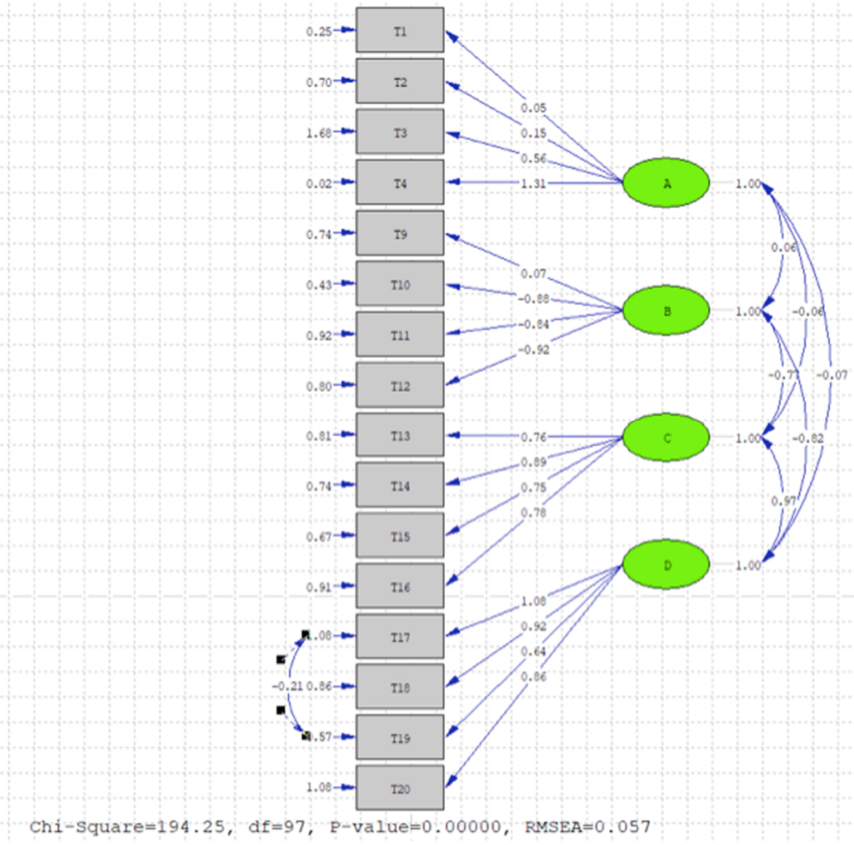

Şekil 1. Teknoloji ve Matematik Tutum Ölçeğine İlişkin Path Diyagramı ve Parametre Tahminleri

Ancak, modifikasyon indeks değerleri incelendiğinde 17 ve 19 numaralı maddeler arasındaki korelasyonun yeniden kontrol edilmesi gerektiği görülmüştür. Bu sebeple, bu madde çiftleri arasında gözlenen hata korelasyonları eklenerek model yeniden incelenmiştir. Elde edilen bulgular, uyum indeksi değerlerinin sırasıyla $\chi^{2}=194.25$, sd=97 RMR=.088, $\mathrm{RMSEA}=.057, \mathrm{SRMR}=.077, \mathrm{GFI}=.93, \mathrm{AGFI}=.90, \mathrm{NFI}=.87, \mathrm{NNFI}=.91, \mathrm{CFI}=.93$ olduğunu ortaya koymuştur. Ki-kare değerinin serbestlik derecesine oranı $\left(\chi^{2} / \mathrm{sd}\right) 2.00^{\prime}$ dır. Bu değerin $5^{\prime}$ ten küçük olması modelin kabul edilebilir düzeyde uyum gösterdiği şeklinde yorumlanmaktadır (Kline, 2016; Sümer, 2000). Uyum indeksi değerleri incelendiğinde bu değerlerin kabul edilebilir düzeyde uyum gösterdiği söylenebilir (Bakınız Tablo 2).

Tablo 2. Uyarlanan ölçeğe ilişkin uyum indeks değerleri ve kabul sınırları

\begin{tabular}{|c|c|c|c|}
\hline $\begin{array}{l}\text { Uyum } \\
\text { İndeksleri }\end{array}$ & $\begin{array}{l}\text { Uyarlanan } \\
\text { Ölçek }\end{array}$ & $\begin{array}{l}\text { Kabul } \\
\text { edilebilir uyum }\end{array}$ & Kaynaklar \\
\hline$\chi^{2}=c^{2} / s d$ & 2.00 & $\leq 5$ & Kline (2016), Sümer (2000) \\
\hline RMR & .088 & $\leq .10$ & $\begin{array}{l}\text { Anderson \& Gerbing (1984), Büyüköztürk \& diğerleri } \\
\text { (2004), Cole (1987) }\end{array}$ \\
\hline RMSEA & .057 & $\leq .08$ & $\begin{array}{l}\text { Anderson \& Gerbing (1984), Büyüköztürk \& diğerleri, } \\
\text { 2004, Cole (1987), Sümer (2000) }\end{array}$ \\
\hline SRMR & .077 & $\leq .08$ & Hu \& Bentler (1999), Sümer (2000) \\
\hline GFI & .93 & $\geq .85$ & $\begin{array}{l}\text { Anderson \& Gerbing (1984), Büyüköztürk ve diğerleri } \\
\text { (2004), Cole (1987) }\end{array}$ \\
\hline AGFI & .90 & $\geq .80$ & Anderson \& Gerbing (1984), Büyüköztürk \& diğerleri \\
\hline
\end{tabular}


(2004), Cole (1987), Hu \& Bentler (1999)

\begin{tabular}{llll} 
NFI & .87 & $\geq .90$ & Kline (2016) \\
CFI & .93 & $\geq .95$ & Kline (2016) \\
\hline
\end{tabular}

İlkokul 4. sınıf öğrencilerinin Matematik ve Teknoloji Tutum Ölçeğinde (MTTÖ) yer alan maddelere ilişkin vermiş oldukları cevapların betimsel istatistiklerine Tablo 3 'te yer verilmiştir.

Tablo 3. MTTÖ alt boyutlarına ilişkin betimsel istatistikler

\begin{tabular}{|c|c|c|c|}
\hline Alt boyutlar & $\mathrm{n}$ & $\bar{X}$ & SS \\
\hline Davranışsal katılım & 311 & 4.045 & .920 \\
\hline Matematiksel güven & 311 & 3.783 & 1.058 \\
\hline Duyuşsal katılım & 311 & 4.276 & .9407 \\
\hline $\begin{array}{l}\text { Teknoloji destekli matematik öğrenmeye yönelik } \\
\text { tutum }\end{array}$ & 311 & 3.293 & 1.208 \\
\hline
\end{tabular}

İlkokul 4. sınıf öğrencilerinin matematik ve teknoloji tutum ölçeği alt boyutlarına vermiş oldukları cevaplar incelendiğinde davranışsal ve duyuşsal katılım ile matematiksel güven alt boyutlarına ilişkin görüşlerinin 'çoğu zaman' aralığına karşılık geldiği görülmektedir. Teknoloji destekli matematik öğrenmeye yönelik tutum alt boyutuna ilişkin olarak öğrencilerin görüşlerinin 'genellikle' aralığına karşılık geldiği belirlenmiştir. MTTÖ ve MKDÖ'ye ilişkin normallik testi sonuçları Tablo 4'te verilmiştir.

Tablo 4. MTTÖ ve MKDÖ'ye ilişkin puanların normallik testi sonuçları

\begin{tabular}{|c|c|c|c|c|c|c|}
\hline & \multicolumn{3}{|c|}{ Kolmogorov-Smirnov } & \multicolumn{3}{|c|}{ Shapiro-Wilk } \\
\hline & İstatistik & $\mathrm{n}$ & $p$ & İstatistik & $\mathrm{n}$ & $\mathrm{p}$ \\
\hline Davranışsal katılım & .167 & 311 & .000 & .883 & 311 & .000 \\
\hline Matematiksel güven & .159 & 311 & .000 & .908 & 311 & .000 \\
\hline Duyuşsal katılım & .223 & 311 & .000 & .774 & 311 & .000 \\
\hline TDMÖT* & .123 & 311 & .000 & .940 & 311 & .000 \\
\hline $\begin{array}{l}\text { Matematik hesaplama } \\
\text { kaygisı }\end{array}$ & 148 & 311 & .000 & .887 & 311 & .000 \\
\hline Uygulama kaygisı & 168 & 311 & .000 & .873 & 311 & .000 \\
\hline $\begin{array}{l}\text { Matematik dersine } \\
\text { yönelik kayg1 }\end{array}$ & .160 & 311 & .000 & .918 & 311 & .000 \\
\hline $\begin{array}{l}\text { Matematik sinav } \\
\text { kaygısı }\end{array}$ & .096 & 311 & .000 & .961 & 311 & .000 \\
\hline $\begin{array}{l}\text { Matematik öğretmeni } \\
\text { kaygıSı }\end{array}$ & .124 & 311 & .000 & .940 & 311 & .000 \\
\hline
\end{tabular}


Kolmogorov-Smirnov testi sonuçlarına göre matematiği öğrenme süreci, matematiği kullanma ve matematiğin doğası alt boyutları için hesaplanan $p$ değerinin $p<.05$ olması sebebiyle normallik varsayımını sağlamadığı görülmüştür.

\section{Matematik ve Teknoloji Tutum Ölçeğinden (MTTÖ) Elde Edilen Bulgular}

Cinsiyet düzeyi değişkenine göre öğrencilerin Matematik ve Teknoloji Tutum Ölçeği (MTTÖ) alt boyutları ortalama puanları arasında anlamlı bir farklılık olup olmadığını belirlemek amacıyla Mann Whitney-U Testi yapılmıştır (Bakınız Tablo 5).

Tablo 5. Cinsiyet değişkenine öğrencilerin MTTÖ alt boyutlarına ilişkin mann whitney-u testi sonuçları

\begin{tabular}{llllllll}
\hline & $\mathrm{N}$ & Cinsiyet & $\begin{array}{c}\text { Sira } \\
\text { Ortalaması }\end{array}$ & $\begin{array}{c}\text { Siraların } \\
\text { Top. }\end{array}$ & $\mathrm{U}$ & $\mathrm{p}$ \\
\hline Davranışsal katılım & 154 & Kız & 164.90 & 25395.00 & 10718.000 & .081 \\
& 157 & Erkek & 147.27 & 23121.00 & & & \\
Matematiksel güven & 154 & Kız & 157.90 & 24316.00 & 11797.000 & .711 & \\
& 157 & Erkek & 154.14 & 24200.00 & & & \\
Duyuşsal katılım & 154 & Kız & 158.15 & 24354.50 & 11758.500 & .668 & \\
& 157 & Erkek & 153.89 & 24161.50 & & & \\
TDMÖT* & 154 & Kız & 162.01 & 24950.00 & 11163.000 & .242 \\
& 157 & Erkek & 150.10 & 23566.00 & & & \\
\hline
\end{tabular}

*TDMÖT: teknoloji destekli matematik öğrenmeye yönelik tutum

Elde edilen bulgular, p>.05 olması sebebiyle cinsiyet değişkenine göre davranışsal katılım, matematiksel güven, duyuşsal katılım ve teknoloji destekli matematik öğrenmeye yönelik tutum alt boyutları arasında anlamlı bir farklılık olmadığını ortaya koymuştur.

Başarı notu değişkenine göre öğrencilerin Matematik ve Teknoloji Tutum Ölçeği (MTTÖ) alt boyutları ortalama puanları arasında anlamlı bir farklılık olup olmadığını belirlemek amacıyla Kruskal Wallis-H Testi yapılmış, elde edilen bulgular Tablo 6'da verilmiştir. 
Tablo 6. Başarı notu değişkenine göre öğrencilerin MTTÖ alt boyutlarına ilişkin kruskal wallis-h testi

\begin{tabular}{|c|c|c|c|c|c|c|c|c|}
\hline \multicolumn{9}{|c|}{ sonuçlar } \\
\hline $\begin{array}{l}\text { Ölçek Alt } \\
\text { Boyutları }\end{array}$ & $\begin{array}{c}\text { Matematik } \\
\text { Başarı } \\
\text { Notu }\end{array}$ & $\mathrm{N}$ & $\bar{x}$ & ss & $\begin{array}{l}\text { Siralar } \\
\text { Ort. }\end{array}$ & $X^{2}$ & $\mathrm{p}$ & $\begin{array}{l}\text { Anlamlı } \\
\text { Farklılık }\end{array}$ \\
\hline \multirow[t]{5}{*}{$\begin{array}{l}\text { Davranışsal } \\
\text { katılım }\end{array}$} & 2 & 13 & 2.78 & .99 & 53.31 & 52.276 & $.000^{*}$ & $\begin{array}{l}2-4,2-5, \\
3-5,4-5\end{array}$ \\
\hline & 3 & 35 & 3.57 & .92 & 107.40 & & & \\
\hline & 4 & 69 & 3.76 & .92 & 126.14 & & & \\
\hline & 5 & 194 & 4.31 & .77 & 182.27 & & & \\
\hline & Toplam & 311 & 4.04 & .92 & & & & \\
\hline \multirow[t]{5}{*}{$\begin{array}{l}\text { Matematiksel } \\
\text { güven }\end{array}$} & 2 & 13 & 2.44 & 1.08 & 59.96 & 75.224 & $.000^{*}$ & $\begin{array}{c}2-5,3-5, \\
4-5\end{array}$ \\
\hline & 3 & 35 & 2.94 & 1.03 & 87.59 & & & \\
\hline & 4 & 69 & 3.37 & .94 & 116.32 & & & \\
\hline & 5 & 194 & 4.17 & .87 & 188.89 & & & \\
\hline & Toplam & 311 & 3.78 & 1.05 & & & & \\
\hline \multirow[t]{5}{*}{$\begin{array}{l}\text { Duyuşsal } \\
\text { katılım }\end{array}$} & 2 & 13 & 3.34 & 1.32 & 80.85 & 48.425 & $.000^{*}$ & $\begin{array}{c}2-5,3-5, \\
4-5\end{array}$ \\
\hline & 3 & 35 & 3.69 & 1.01 & 98.50 & & & \\
\hline & 4 & 69 & 4.01 & 1.03 & 127.82 & & & \\
\hline & 5 & 194 & 4.53 & .73 & 181.43 & & & \\
\hline & Toplam & 311 & 4.27 & .94 & & & & \\
\hline \multirow[t]{5}{*}{ *TDMÖT } & 2 & 13 & 3.30 & 1.34 & 158.23 & 4.603 & .203 & .203 \\
\hline & 3 & 35 & 2.92 & 1.06 & 125.53 & & & \\
\hline & 4 & 69 & 3.38 & 1.17 & 161.96 & & & \\
\hline & 5 & 194 & 3.32 & 1.23 & 159.23 & & & \\
\hline & Toplam & 311 & 3.29 & 1.20 & & & & \\
\hline
\end{tabular}

Tablo 6 incelendiğinde matematik başarı notu değişkenine göre öğrencilerin davranışsal tutum, matematiksel güven ve duyuşsal katılım alt boyutlarına ilişkin ortalama puanları arasında $\mathrm{p}<.05$ olması sebebiyle anlamlı bir farklılık olduğunu göstermiştir. Ancak, başarı değişkenine göre öğrencilerin teknoloji destekli matematik öğrenmeye yönelik tutum alt boyutuna yönelik görüşleri arasında p>.05 olması sebebiyle anlamlı bir farklılık olmadığı belirlemiştir. 
Matematik Kaygısı Derecelendirme Ölçeğinden Elde Edilen Bulgular

İlkokul 4. sınıf öğrencilerinin Matematik Kaygısı Derecelendirme Ölçeğinde (MKDÖ) yer alan maddelere ilişkin vermiş oldukları cevapların betimsel istatistiklerine Tablo 7' de yer verilmiştir.

Tablo 7. MKDÖ alt boyutlarına ilişkin betimsel istatistikler

\begin{tabular}{lccc}
\hline \multicolumn{1}{c}{ Alt boyutlar } & $\mathrm{N}$ & $\bar{x}$ & ss \\
\hline Matematik hesaplama kaygıSı & 311 & 1.946 & .890 \\
Uygulama kaygısı & 311 & 1.853 & .857 \\
Matematik dersine yönelik kaygı & 311 & 2.268 & 1.033 \\
Matematik sınav kaygısı & 311 & 3.243 & 1.111 \\
Matematik öğretmeni kaygısı & 311 & 2.541 & 1.113 \\
\hline
\end{tabular}

Öğrencilerin Matematik Kaygısı Derecelendirme Ölçeğinde yer alan alt boyutlar matematik hesaplama kaygısı, uygulama kaygısı ve matematik dersine yönelik kaygı alt boyutlarına yönelik görüşlerinin 'çok az' aralığına karşılık geldiği belirlenmiştir. Öğrencilerin matematik sınav kaygısı ve matematik öğretmeni kaygısına yönelik görüşlerinin ise 'orta derecede' aralığına karşılık geldiği görülmektedir.

Cinsiyet değişkenine göre öğrencilerin Matematik Kaygısı Derecelendirme Ölçeği (MKDÖ) alt boyutları ortalama puanları arasında anlamlı bir farklılık olup olmadığını belirlemek amacıyla Mann Whitney-U yapılmıştır (Bakınız Tablo 8).

Tablo 8. Cinsiyet değişkenine öğrencilerin MKDÖ alt boyutlarına ilişkin mann whitney-u testi sonuçlar

\begin{tabular}{lcccccc}
\hline & $\mathrm{N}$ & Cinsiyet & $\begin{array}{c}\text { Sira } \\
\text { Ortalamas }\end{array}$ & $\begin{array}{c}\text { Siraların } \\
\text { Top. }\end{array}$ & $\mathrm{U}$ & $\mathrm{p}$ \\
\hline Matematik hesaplama kaygısı & 154 & Kiz & 152.10 & 23423.50 & 11488.500 & .447 \\
& 157 & Erkek & 159.82 & 25092.50 & & \\
Uygulama kaygısı & 154 & Kiz & 157.65 & 24278.50 & 11834.500 & .747 \\
& 157 & Erkek & 154.38 & 24237.50 & & \\
Matematik dersine yönelik kaygı & 154 & Kiz & 159.36 & 24541.00 & 11572.000 & .512 \\
& 157 & Erkek & 152.71 & 23975.00 & & \\
Matematik sinav kaygisı & 154 & Kiz & 159.53 & 24567.00 & 11546.000 & .493 \\
& 157 & Erkek & 152.54 & 23949.00 & & \\
Matematik öğretmeni kaygis1 & 154 & Kiz & 152.36 & 23463.00 & 11528.000 & .478 \\
& 157 & Erkek & 159.57 & 25053.00 & & \\
\hline
\end{tabular}

Elde edilen bulgular, cinsiyet değişkenine göre kız ve erkek öğrenciler arasında matematik kaygısı söz konusu olduğunda anlamlı bir farklılık olmadığını ortaya koymuştur. Başarı notu değişkenine göre öğrencilerin Matematik Kaygısı Derecelendirme Ölçeği (MKDÖ) alt boyutları ortalama puanları arasında anlamlı bir farklılık olup olmadığını belirlemek amacıyla Kruskal Wallis-H Testi yapılmıştır (Bakınız Tablo 9). 
Tablo 9. Başarı notu değişkenine öğrencilerin MKDÖ alt boyutlarına ilişkin kruskal wallis-h testi sonuçları

\begin{tabular}{|c|c|c|c|c|c|c|c|c|}
\hline $\begin{array}{l}\text { Ölçek Alt } \\
\text { Boyutları }\end{array}$ & $\begin{array}{c}\text { Matematik } \\
\text { Başarı Notu }\end{array}$ & $\mathrm{n}$ & $\bar{x}$ & ss & $\begin{array}{l}\text { Siralar } \\
\text { Ort. }\end{array}$ & $X^{2}$ & $\mathrm{p}$ & $\begin{array}{l}\text { Anlamlı } \\
\text { Farklılık }\end{array}$ \\
\hline \multirow{5}{*}{$\begin{array}{c}\text { Matematik } \\
\text { hesaplama } \\
\text { kaygisı }\end{array}$} & 2 & 13 & 2.53 & .65 & 227.15 & 50.547 & $.000^{*}$ & $\begin{array}{c}2-5,3-5, \\
4-5\end{array}$ \\
\hline & 3 & 35 & 2.41 & .92 & 205.94 & & & \\
\hline & 4 & 69 & 2.37 & 1.03 & 194.96 & & & \\
\hline & 5 & 194 & 1.67 & .71 & 128.37 & & & \\
\hline & Toplam & 311 & 1.94 & .89 & & & & \\
\hline \multirow[t]{5}{*}{$\begin{array}{l}\text { Uygulama } \\
\text { kaygis1 }\end{array}$} & 2 & 13 & 2.50 & .78 & 226.73 & 43.657 & $.000^{*}$ & $\begin{array}{c}2-5,3-5, \\
4-5\end{array}$ \\
\hline & 3 & 35 & 2.06 & .87 & 180.77 & & & \\
\hline & 4 & 69 & 2.32 & 1.00 & 200.86 & & & \\
\hline & 5 & 194 & 1.60 & .68 & 130.84 & & & \\
\hline & Toplam & 311 & 1.85 & .85 & & & & \\
\hline \multirow{5}{*}{$\begin{array}{l}\text { Matematik } \\
\text { dersine } \\
\text { yönelik } \\
\text { kayg1 }\end{array}$} & 2 & 13 & 2.79 & 1.09 & 202.46 & 36.269 & $.000^{*}$ & $\begin{array}{c}2-5,3-5, \\
4-5\end{array}$ \\
\hline & 3 & 35 & 2.79 & .97 & 204.11 & & & \\
\hline & 4 & 69 & 2.66 & 1.11 & 188.71 & & & \\
\hline & 5 & 194 & 1.99 & .91 & 132.57 & & & \\
\hline & Toplam & 311 & 2.26 & 1.03 & & & & \\
\hline \multirow{5}{*}{$\begin{array}{c}\text { Matematik } \\
\text { sinav } \\
\text { kaygisı }\end{array}$} & 2 & 13 & 3.07 & .95 & 139.73 & 7.221 & $.000^{*}$ & $3-5$ \\
\hline & 3 & 35 & 3.62 & .83 & 185.44 & & & \\
\hline & 4 & 69 & 3.39 & 1.05 & 168.18 & & & \\
\hline & 5 & 194 & 3.13 & 1.16 & 147.45 & & & \\
\hline & Toplam & 311 & 3.24 & 1.11 & & & & \\
\hline \multirow{5}{*}{$\begin{array}{l}\text { Matematik } \\
\text { öğretmeni } \\
\text { kaygısı }\end{array}$} & 2 & 13 & 3.10 & .88 & 208.00 & 34.558 & $.000^{*}$ & $\begin{array}{c}2-5,3-5, \\
4-5\end{array}$ \\
\hline & 3 & 35 & 3.07 & 1.12 & 198.00 & & & \\
\hline & 4 & 69 & 2.95 & 1.12 & 189.71 & & & \\
\hline & 5 & 194 & 2.25 & 1.02 & 132.95 & & & \\
\hline & Toplam & 311 & 2.54 & 1.11 & & & & \\
\hline
\end{tabular}

${ }^{*} \mathrm{p}<.05$

Benzer şekilde, başarı notu değişkenine göre öğrencilerin Matematik Kaygısı Derecelendirme Ölçeği alt boyutları ortalama puanları arasında $p<0.05$ olması sebebiyle anlamlı bir farklılık olduğu görülmektedir. Bu durum başarı notunun öğrencilerin matematik hesaplama kaygısı, uygulama kayg1sı, matematik dersine yönelik kaygı, matematik sınav kaygısı ve matematik öğretmeni kaygısına yönelik görüşlerinde önemli bir rolü olduğunu ortaya koymuştur. 
Öğrencilerin MTTÖ ve MKDÖ alt boyutlarına ilişkin görüşleri arasındaki ilişkinin incelenmesi amacıyla Spearman's rho korelasyon katsayıları hesaplanmıştır (Bkz Tablo 10).

Tablo 10. MTTÖ ile MKDÖ alt boyutları arasındaki korelasyon sonuçları

\begin{tabular}{llllll}
\hline & $\begin{array}{l}\text { Matematik } \\
\text { hesaplama } \\
\text { kaygısı }\end{array}$ & $\begin{array}{l}\text { Uygulama } \\
\text { kaygısı }\end{array}$ & $\begin{array}{l}\text { Matematik } \\
\text { dersine } \\
\text { yönelik } \\
\text { kayg1 }\end{array}$ & $\begin{array}{l}\text { Matematik } \\
\text { sinav kaygısı }\end{array}$ & $\begin{array}{l}\text { Matematik } \\
\text { ŏgretmeni } \\
\text { kaygısı }\end{array}$ \\
\hline $\begin{array}{l}\text { Davranışsal } \\
\text { katılım } \\
\text { Matematiksel } \\
\text { güven }\end{array}$ &.$- .426^{* *}$ & $-.394^{* *}$ & $-.327^{* *}$ & $-.127^{* *}$ & $-.338^{* *}$ \\
$\begin{array}{l}\text { Duyuşsal } \\
\text { katılım } \\
\text { TDMÖT* }\end{array}$ & $-.453^{* *}$ & $-.399^{* *}$ & $-.404^{* *}$ & $-.183^{* *}$ & $-.412^{* *}$ \\
\hline ** p=.05 *TDMÖT: teknoloji destekli matematik öğrenmeye yönelik tutum & - & $-.286^{* *}$ \\
\end{tabular}

Cohen (1988) korelasyon katsayı değerleri dikkate alındığında, .10-.29 arasını küçük, .30-.49 arasını orta, .50-1.0 arasını anlamlı ve güçlü ilişki olduğu şeklinde yorumlanmaktadır. $\mathrm{Bu}$ araştırmada, öğrencilerin Matematik ve Teknoloji Tutum ölçeği alt boyutları, davranışsal katılım, matematiksel güven ve duyuşsal katılım boyutları kapsamında zayıf ve orta derecede anlamlı bir ilişki olduğu görülmektedir. Öğrencilerin teknoloji destekli matematik öğrenmeye yönelik tutum ile matematik kaygısı ölçeği alt boyutlarına yönelik görüşleri arasında anlamlı bir ilişki olmadığı belirlenmiştir.

\section{Tartışma ve Sonuç}

Bu çalışmanda öncelikli olarak Pierce, Stacey ve Barkatsas (2007) tarafından geliştirilen Matematik ve Teknoloji Tutum Ölçeğinin Türkçeye uyarlama çalışması yapılmıştır. Elde edilen bulgular, dördüncü sınıf öğrencileri için uyarlama çalışması yapılan ölçeğin geçerli ve güvenilir bir ölçme aracı olduğu belirlenmiştir. Uyarlanan ölçek, özgün halinde yer alan beş alt boyuttan dördünü içerecek şekilde bir yapı oluşturmuştur. Uyarlanan ölçekte, teknoloji kullanımıyla ilgili güven alt boyutunda yer alan maddelerin toplam test korelasyon değerlerinin .20 değerinin altında olması sebebiyle çıkarılmıştır. Aynı ölçek, lise düzeyinde öğrenim gören öğrenciler için Duru, Peker ve Akçakın (2010) tarafından uyarlanmış ve özgün haliyle aynı şekilde 5 alt faktörden oluştuğu belirlenmiştir. Elde edilen sonuçlar gösteriyor ki ilkokul öğrencileri için uyarlanan ölçeğin teknoloji kullanımıyla ilgili güven alt boyutu dışında özgün ve lise öğrencileri için uyarlanan haline 
benzer bir yapı göstermiştir. Uyarlanan ölçek beşli likert tipinde olup 16 maddeden oluşmaktadır. Ölçeğin bütünü için güvenilirlik katsayısı .89 olarak hesaplanmıştır. Uyarlanan ölçek davranışsal katılım $(1,2,3,4)$, matematiksel güven $(9,10,11,12)$, duyuşsal katılım $(13,14,15,16)$ ve teknoloji destekli matematik öğrenmeye yönelik tutum $(17,18,19,20)$ olmak üzere 4 alt boyuttan oluşmaktadır. Ölçek alt boyutları için Cronbach alfa güvenirlik katsayısı sırasıyla $.77, .85, .82, .80$ olarak hesaplanmıştır.

Elde edilen sonuçlar, ilkokul 4. sınıf öğrencilerinin teknoloji destekli matematik öğrenmeye yönelik tutumlarının genel olarak olumlu ve gelişmiş olduğunu ortaya koymuştur. Dowker, Cheriton, Horton ve Mark (2019) ilkokul 1. sınıf öğrencilerinin matematik dersine yönelik tutumlarının olumlu olduğunu ancak yaşı daha büyük ilkokul öğrencilerine kıyasla düşük olduğunu belirlemiştir. Matematiksel güveni Pierce, Stacey ve Barkatsas (2007) öğrencinin iyi sonuçlar alma becerisi ve matematikte karşılaştığı güçlüklerin üstesinden gelmeye ilişkin algısı olarak tanımlamaktadır. Matematik söz konusu olduğunda okula, öğrenme etkinliklerine katılmaya yönelik karşı pozitif bir bakış açısı 'davranışsal katılım olarak tanımlanmaktadır. Öğrencilerin bu derse karşı nasıl hissettikleri ise ‘duyuşsal katılım' olarak ifade edilmiştir. Bu durum sınıf ortamında duyuşsal bir reaksiyon oluşturarak sıkılma, mutluluk ve ait olma şekilde karşımıza çıkmaktadır (Pierce, Stacey \& Barkatsas, 2007). Bu çalışma 4. sınıf öğrencilerinin çoğunlukla matematik dersi söz konusu olduğunda başarılı olma, yapabilme ve iyi notlar alma noktasında kendilerine ve becerilerine güven duydukları belirlenmiştir. Öğrencilerin çoğunlukla matematik dersinde yapılan çalışmalara katılmada istekli ve olumlu duygulara sahip oldukları söylenebilir. Teknoloji destekli matematik öğrenmeye yönelik olarak öğrencilerin tutumlarının olumlu olduğu belirlenmiştir. Matematik derslerinde teknoloji kullanımının ilgiyi artırıcı ve öğrenmeye yardımcı bir unsur olarak karşımıza çıktığı belirlenmiştir. Bu çalışmadan elde edilen sonuçlara paralel olarak, Pierce, Stacey ve Barkatsas (2007) 8.-10. Sınıfta öğrenim gören öğrencilerin davranışsal katılım, duyuşsal katılım, matematiksel güven ve teknoloji destekli matematik öğrenmeye yönelik tutumlarının olumlu ve yüksek olduğunu belirlemiştir.

Cinsiyet değişkeni söz konusu olduğunda, elde edilen sonuçlar, kız ve erkek öğrencilerin teknolojiyle beraber matematik öğrenmeye yönelik tutumları (davranışsal katılım, matematiksel güven, duyuşsal katılım ve teknoloji destekli matematik öğrenmeye yönelik tutum) arasında anlamlı bir farklılık olmadığını ortaya koymuştur. Ancak, Pierce, Stacey ve Barkatsas (2007) cinsiyet değişkenine göre kız ve erkek öğrencilerin tutumları 
arasında anlamlı bir farklılığın olduğunu belirlemiştir. Bu farklılığın erkek öğrencilerin lehine olduğu görülmektedir. Bazı araştırmalar ise Pierce ve Stacey (2004) ile Vale ve Leder (2004) tarafından yapılan araştırma sonuçları teknoloji destekli matematik öğrenmeye yönelik olarak kız ve erkek öğrenciler arasında anlamlı farklılık olduğunu ve bu farklılığın erkekler lehine olduğu belirlemiştir. Duru, Peker ve Akçakın (2010) ise davranışsal katılım ve duyuşsal katılım alt boyutlarında kızların lehine, bilgisayar kullanımına yönelik güven söz konusu olduğunda erkekler lehine farklılık olduğu belirlenmiştir. Cinsiyet değişkenine göre öğrencilerin matematiksel güven ve bilgisayar destekli matematik öğretimine yönelik tutumları arasında anlamlı bir farklılık bulunmamıştır.

Matematik başarı notu değişkenine göre öğrencilerin davranışsal tutum, matematiksel güven ve duyuşsal katılıma yönelik görüşleri arasında anlamlı bir farklılık olduğunu göstermiştir. Ancak, başarı değişkenine göre öğrencilerin teknoloji destekli matematik öğrenmeye yönelik tutumları arasında anlamlı bir farklılık olmadığı belirlemiştir. Araştırmalar matematik öğretiminde teknoloji destekli matematik öğrenmenin öğrencilerin akademik başarıları ve motivasyonları üzerinde olumlu bir etkisinin olduğunu vurgulamaktadır (Işıksal \& Akşar, 2003). Bununla beraber, Haciomeroglu (2017) öğrencilerin başarıları ile matematik dersine yönelik tutumları arasında anlamlı bir farklılık olmadığını belirlemiştir. $\mathrm{Bu}$ araştırma sonuçları matematik başarısının öğrencilerin derse katılım noktasında ve derse yönelik hissedilen sıkılma, mutluluk ve ait olma gibi duyuşsal özelliklerin önemli bir rolü olduğuna işaret etmektedir. Ancak, öğrencilerin matematik başarıları ile teknoloji destekli matematik öğrenmeye yönelik tutumları arasında anlamlı bir farklılık tespit edilmemiştir. Bu durum, 4. sınıf öğrencilerinin başarılarında teknoloji destekli matematik öğrenmenin önemli bir rolü olmadığına işaret etmektedir.

İlkokul 4. sınıf öğrencilerinin matematik hesaplama kaygısı, uygulama kaygısı ve matematik dersine yönelik kaygı düzeylerinin düşük olduğu belirlenirken matematik sınav kaygısı ve matematik öğretmeni kaygı düzeylerinin orta düzeyde olduğu tespit edilmiştir. Benzer şekilde, Haciomeroglu (2017) tarafından yapılan çalışmada ilkokul 4. Sınıf öğrencilerinin matematik kaygı düzeylerinin düşük olduğu belirlenmiştir. Elde edilen sonuçlar, bu çalışmaya katılan öğrencilerin matematik öğrenmekten hoşlandığına işaret etmektedir. Ancak, sınavın ve öğretmenin matematik sınıflarındaki davranışlarının öğrencilerin kaygı düzeylerini artırdığına işaret etmektedir. Cinsiyet değişkeninin kız ve erkek öğrencilerin kaygı düzeyleri arasında anlamlı bir farklılık oluşturmadığı belirlenmiştir. 
Benzer şekilde Haciomeroglu (2017) ile Mutlu, Söylemez ve Yasul (2017) kız ve erkek öğrencileri matematik kaygı düzeyleri arasında anlamlı bir farklılık olmadığını tespit etmiştir. Bu durum, bu çalışmaya katılan kız ve erkek öğrencilerin matematik öğrenmeye ilişkin benzer deneyimlere sahip olduklarına işaret etmektedir. Başarı notu değişkenine göre öğrencilerin matematik kaygı düzeyleri (matematik hesaplama kaygısı, uygulama kaygısı, matematik dersine yönelik kaygı, matematik sınav kaygısı ve matematik öğretmeni kaygısı) arasında anlamlı bir farklılık olduğunu belirlemiştir. Buna paralel olarak, Haciomeroglu (2017) ile Mutlu, Söylemez ve Yasul (2017) Matematik başarısı ile kaygı düzeyi arasında anlamlı ve negatif bir ilişki olduğunu belirlemiştir. Öğrencilerin başarı düzeyi arttıkça kaygı düzeyinin azaldığı görülmektedir.

Son on yılda teknoloji destekli matematik öğretimi okul öncesinden yükseköğretime yaygın olarak kullanılmaktadır. İlkokul düzeyinde bilgisayar, projeksiyon ve/veya akıllı tahta sınıflarda sıklıkla öğretmenler tarafından kullanılmaktadır. Araştırmalar öğrencilerin matematiğe yönelik olumlu bir tutumla ilkokula başladığını ancak süreçte edinilen deneyimlerin kaygı ve tutumları üzerinde önemli bir rol oynadığını belirtmektedir (Philippou \& Christou, 1998). Matematik kaygısının ve bu derse yönelik olumsuz tutumun erken yaşlarda oluşmaya başladığı düşünüldüğünde öğrencilerin ilgisini çekecek, eğlenceli ve motive edici etkinliklerde teknolojinin yardımcı ve destekleyici olarak kullanılması önemlidir. $\mathrm{Bu}$ şekilde öğrencilerin matematiğe yönelik olumlu tutumlar geliştirmesi sağlanarak bu derse ve derse bağlı olarak öğretmene ve sınava yönelik kaygı düzeylerinin azaltılması sağlanabilir.

\section{Kaynaklar}

Aiken, L. R. (1970). Attitudes toward mathematics. Review of Educational Research, 40(4), 551596.

Aiken, L.R. (1974). Two scales of attitude toward mathematics. Journal for Research in Mathematics Education, 5(2), 67-71.

Anderson, J.C. \& Gerbing D.W. (1984). The effect of sampling error on convergence, improper solutions, and goodness-of- fit indices for maximum likelihood confirmatory factor analysis. Psychometrika, 49, 155-173.

Ashcraft, M. H. (2002). Math anxiety: Personal, educational, and cognitive consequences. Directions in Psychological Science, 11(5), 181-185.

Arı, K., Savas, E. \& Konca, S. (2010). İlköğretim 7. sınıf öğrencilerinin matematik kaygısının nedenlerinin incelenmesi. Selçuk Üniversitesi Ahmet Keleşoğlu Eğitim Fakültesi Dergisi, $29,211-230$. 
Baloglu, M., \& Balgalmis, E. (2010). The adaptation of the mathematics anxiety rating scaleelementary form into turkish, language validity, and preliminary psychometric investigation. Educational Sciences: Theory and Practice, 10(1), 101-110.

Barkatsas, A., Kasimatis, K. \& Gialamas V. (2009). Learning secondary mathematics with technology: Exploring the complex interrelationship between students' attitudes, engagement, gender and achievement. Computers \& Education, 52, 562-570.

Büyüköztürk, Ş., Akgün, Ö. E., Kahveci, Ö. \& Demirel, F. (2004). Güdülenme ve öğrenme stratejileri ölçeğinin Türkçe formunun geçerlik ve güvenirlik çalışması. Kuram ve Uygulamada Ĕ̆itim Bilimleri, 4(2), 210-239.

Chipman, S. F., Krantz, D. H. \& Silver, R. (1992). Mathematics anxiety and science careers among able college women. Psychological Science, 3, 292-295.

Cohen, J. (1988). Statistical power analysis for the behavioral sciences. Mahwah, NJ: Lawrence Erlbaum Associates.

Cole, D.A. (1987). Utility of confirmatory factor analysis in test validation research. Journal of Consulting and Clinical Psychology, 55, 1019-1031.

Çelik, H.C. \& Ceylan, H. (2009). Lise öğrencilerinin matematik ve bilgisayar tutumlarının çeşitli değişkenler açısından karşılaştırılması. Pamukkale Üniversitesi Ĕ̆itim Fakültesi Dergisi, 26, 92-101.

Çokluk, Ö., Şekercioğlu, G. \& Büyüköztürk, Ş. (2010). Sosyal bilimler için çok değişkenli istatistik: SPSS ve LISREL uygulamaları. Ankara: Pegem Akademik.

Dowker, A. Cheriton, O. Horton, R. \& Mark, W. (2019). Relationships between attitudes and performance in young children's mathematics. Educational Studies in Mathematics, 100(3), 211-230.

Duru A., Peker M. \& Akçakın V. (2010). Lise öğrencilerinin bilgisayar destekli matematik öğrenmeye yönelik tutumları. Turkish Journal of Computer and Mathematics Education, 1(3), 264-284.

Dursun, S. \& Bindak, R. (2011). İlköğretim ikinci kademe öğrencilerinin matematik kaygılarının incelenmesi. Cumhuriyet Üniversitesi Sosyal Bilimler Dergisi, 35(1),18-21.

Field, A. (2005). Discovering statistics using SPSS. Thousand Oaks, CA: Sage Publications, Inc.

Fogarty, G., Cretchley, P., Harman, C., Ellerton, N., \& Konki, N. (2001). Validation of a questionnaire to measure mathematics confidence, computer confidence, and attitudes towards the use of technology for learning mathematics. Mathematics Education Research Journal, 13, 154-160.

Galbraith, P. \& Haines, C. (1998). Disentangling the nexus: attitudes to mathematics and technology in a computer learning environment. Educational Studies in Mathematics, 36, 275-290.

Gülburnu, M. \& Yıldırım, K. (2015). İlkokul ve ortaokul öğrencilerine yönelik matematik tutum ölçeği geliştirilmesi ve uygulanması. VI. Uluslararası Türkiye Eğitim Araştırmaları Kongresi içinde (s.568-581). Ankara: Hacettepe Üniversitesi.

Hacıömeroğlu, G. (2017). Matematiğe yönelik tutum ölçeği kısa formunun geçerlik ve güvenirlik çalışması. Journal of Computer and Education Research, 5(9), 84-99. 
Haciomeroglu, G. (2017). Reciprocal relationships between mathematics anxiety and attitude towards mathematics in elementary school students. Acta Didactica Napocensia Journal, 10(3), 59-68.

Haladyna, T., Shaughnessy, J., \& Shaughnessy, J. M. (1983). A causal analysis of attitude toward mathematics. Journal for Research in Mathematics Education, 14(1), 19-29.

House, J.D., (1995). The predictive relationship between academic self-concept, achievement expectancies, and grade performance in college calculus. The Journal of Social Psychology 135,1, 111-112.

Hu, L.T., \& Bentler, P.M. (1999). Cut-off criteria for fit indexes in covariance structure analysis: Conventional criteria versus new alternatives. Structural Equation Modeling, 6, 1-55.

Işıksal, M. \& Akşar, P.(2003). İlköğretim öğrencileri için matematik ve bilgisayar öz-yeterlik algısı ölçekleri. Hacettepe Üniversitesi Ĕ̆itim Fakültesi Dergisi, 25, 109-118.

Kan, A. (2009). Ölçme sonuçları üzerinde istatistiksel işlemler. H. Atılgan (Ed.), Eğitimde ölçme ve değerlendirme (ss.397-456), Anı Yayıncılık: Ankara.

Karasar, N. (2003). Bilimsel araştırma yöntemleri. Ankara: Nobel Yayın-Dağıtım.

Klein, P. (1986). A handbook of test construction. London: Routledge.

Kline, R. B.(2016). Principles and practice of structural equation modeling. The Guilford Press, New York: NY.

Kutluca, T., Alpay, F.N. \& Kutluca, S. (2015). 8. sinıf öğrencilerinin matematik kayg1 düzeylerine etki eden faktörlerin incelenmesi. Dicle Üniversitesi Ziya Gökalp Eğitim Fakültesi Dergisi, 25, 202-214.

Lim S. Y., Chapman E. (2013). Development of a short form of the attitudes toward mathematics inventory. Educational Studies in Mathematics, 82(1), 145-164.

Ma, X, \& Kishor, N. (1997). Assessing the relationship between attitude toward mathematics and achievement in mathematics: A meta-analysis. Journal for Research in Mathematics Education, 28(1), 26-47.

Mutlu, Y., Söylemez, I., \& Yasul, A. F. (2017). İlkokul öğrencilerinin matematik kaygısı ile matematik başarıları arasındaki ilişkinin incelenmesi. Journal of Human Sciences, 14(4), 4425-4434.

Neale, D. C. (1969). The role of attitudes in learning mathematics. The Arithmetic Teacher, 16, 631-640.

Pierce, R. \& Stacey, K. (2004). A framework for monitoring progress and planning teaching towards the effective use of computer algebra systems. International Journal of Computers for Mathematical Learning, 9, 59-93.

Pierce, R., Stacey, K., \& Barkatsas, A. N. (2007). A scale for monitoring students' attitudes to learning mathematics with technology. Computers $\mathcal{E}$ Education, 48(2), 285-300.

Philippou, G. N. \& Christou, C. (1998). The effects of a preparatory mathematics program in changing prospective teachers' attitudes towards mathematics. Educational Studies in Mathematics, 35, 189-206. 
Reed, H. C., Drijvers, P., \& Kirschner, P. A. (2010). Effects of attitudes and behaviours on learning mathematics with computer tools. Computers \& Education, 55, 1-15.

Richardson, F. C. \& Suinn, R. M. (1972). The mathematics anxiety rating scale: psychometric data. Journal of Counseling Psychology, 19, 551-554.

Suinn R.M (1988). The measurement of mathematics anxiety: the mathematics anxiety rating scale for adolescents -MARS-A. Journal of Clinical Psychology, 38, 576-580.

Sümer, N. (2000). Yapısal eşitlik modelleri: temel kavramlar ve örnek uygulamalar. Türk Psikoloji Yazıları, 3(6), 49-74.

Tapia, M. \& Marsh, G. E.II. (2004). An instrument to measure mathematics attitudes. Academic Exchange Quarterly, 8(2), 16-21.

Tavşancıl, E. (2005). Tutumların ölçülmesi ve SPSS ile veri analizi. Ankara: Nobel Yayın Dağıtım.

Vale, C., \& Leder, G. (2004). Student views of computer-based mathematics in the middle years: does gender make a difference? Educational Studies in Mathematics, 56, 287-312.

Yaratan, H., \& Kasapoğlu, L. (2012). Eighth grade students' attitude, anxiety, and achievement pertaining to mathematics lessons. Procedia-Social and Behavioral Sciences, $46,162-171$.

Yüksel-Şahin, F. (2008). Mathematics anxiety among 4th and 5th grade Turkish elementary school students. International Electronic Journal of Mathematics Education, 3(3), 179-192.

Zakaria, E. \& Nordin, N. M. (2008). The effects of mathematics anxiety on matriculation students as related to motivation and achievement. Eurasia Journal of Mathematics, Science \& Technology Education, 4(1), 27-30. 